\title{
An Evaluation of Condensed Molasses Solubles (CMS) as a Source of Nitrogen for Ruminal Microbes In Vitro
}

\author{
J. M. Yeo*, C. H. Kim**, J. H. Lee*, W. G. Nho*, S. H. Lee* and W. Y. Kim* \\ Korean National Agricultural College*, Hankyoung National University** \\ 반추위 미생물의 질소공급원으로서 Condensed Molasses \\ Solubles (CMS)의 사료 가치 평가 \\ 여준모* · 김창현** . 이장형* · 노환국* . 이성훈* . 김완영* \\ 한국농업전문학교*, 한경대학교**
}

요 약

본 연구는 monosodium glutamate의 부산물인 condensed molasses solubles (CMS)가 반추가축의 질소 공 급원으로서 반추위 미생물 단백질 합성에 미치는 영향을 in vitro 실험을 통하여 조사하였다. 실험 1에서 는 반추위 미생물에 대한 질소 공급원으로서 $\mathrm{CMS}$ 의 가치를 요소와 비교하였고, 실험 2는 미생물의 생 성양이 최대가 되는 시간대를 조사하기 위하여 수행하였고, 실험 3 에서는 실험 1 과 2 에서 배양 후 실시 된 원심분리 $(1000 \mathrm{~g} \times 5$ 분 $)$ 에 의해 생성된 침전물이 총 질소의 공급양과 측정된 질소양에 차이를 발생시 킴에 따라 침전물의 성분을 조사하고자 수행하였고, 실험 4는 배양 2시간대에서 CMS와 요소로부터 발 생되는 암모니아의 발생양을 조사하기 위하여 수행하였다. 이상의 결과를 요약하면 다음과 같다.

1. 반추위 미생물태 질소 합성량은 $\mathrm{CMS} /$ 당밀 처리구 $(7.79 \mathrm{mg} / 100 \mathrm{ml})$ 와 요소/당밀 $(7.61 \mathrm{mg} / 100 \mathrm{ml})$ 의 처 리구간에 유의적인 차이는 없었지만 $\mathrm{CMS}$ /당밀의 처리구가 암모니아태 질소의 함량을 유의적으로 감소시켰다.

2. $\mathrm{CMS}$ /당밀 처리구의 암모니아태 질소 함량과 $\mathrm{pH}$ 는 당밀/요소 처리구보다 유의적으로 감소하였다. 하지만 미생물태 질소의 양은 처리구간에 차이가 없었다. 최대 미생물의 성장률은 배양 후 10 시간 에서 발생하였다.

3. 당밀 대신 $100 \%$ 수용성인 설탕을 이용하였을 경우에도 침전물이 발생하여 침전물이 당밀에 의한 것이 아님이 확인되었고, 또한 배양 시간이 짧았을 경우 (2시간) 질소의 손실양도 상대적으로 크게 감소하여, 총 질소의 공급양과 측정된 질소양의 차이는 침전물에 박테리아가 포함되었기 때문인 것으로 조사되었다.

4. 배양 2시간 동안 $\mathrm{CMS}$ 로부터 발생되는 암모니아의 생성속도는 요소로부터 발생되는 속도보다 유 의적으로 빠르게 나타났다.

본 실험의 결과 CMS는 반추위 미생물 단백질을 합성하는 데 있어 최소한 요소의 가치를 지니고 있음이 조사되었다.

(Key words : Condensed molasses solubles (CMS), Microbial protein synthesis, Rumen)

\section{I . INTRODUCTION}

The most widely used source of NPN is urea but other NPN compounds also have been studied using by-products from fermentation of molasses. (Karalazos and Swan, 1977; Chen et al., 1981; Potter et al., 1985; Ha et al., 1998; Lee et al., 1998; Yeo et al., 2004). However, according to the final products, the names of by-products are various, for instance citrus

\footnotetext{
Corresponding author : Wan-Young Kim, 11-1 Dongwha-ri, Bongdam-eup, Hwaseong-si, Gyeonggi-do, 445-890, Korea.

Phone : 031-229-5032, Fax : 031-229-5055, E-mail : wykim@rda.go.kr
} 
condensed molasses solubles (CCMS), a by-product from alcohol and ammonium lignin sulfonate (ALS), a by-product from wood pulp production. In addition, the composition of by-products from fermentation of molasses, especially its nitrogen content, was very variable in each experiment. There were no in vitro studies using condensed molasses solubles (CMS) from the fermentation of molasses to produce monosodium glutamate (MSG). The CMS used in the present experiment contained high levels of ammonia nitrogen.

In view of these observations, it was decided to evaluate CMS as a source of nitrogen for ruminal bacteria in vitro. In experiment 1 , as compared with urea, the value of CMS as nitrogen source was examined. In experiment 2, to determine the time needed for maximal response of microbial synthesis, the treatments were incubated for increasing times (from $6 \mathrm{~h}$ to $16 \mathrm{~h})$.

One problem was that a sediment was found after incubation in experiments 1 and 2, even though the inoculum had been centrifuged to remove feed particles and protozoa before incubation. To solve those problems, it was decided to avoid formation of sediment using sugar instead of molasses or a shorter time incubation (experiments 3 and 4), because it was assumed that some proportion of microorganisms might attach to some of insoluble materials of molasses or CMS. Furthermore in experiment 4, because the extent to which ammonia nitrogen is released from CMS and urea before $6 \mathrm{~h}$ of incubation was uncertain, it was decided to examine the peaks of concentration of ammonia nitrogen released from CMS and urea by sampling after a $2 \mathrm{~h}$ incubation period.

\section{MATERIALS \& METHODS}

\section{Animal and management}

A non-lactating Friesian cow fitted with a permanent rumen cannula was used as a donor animal for rumen digesta. The cow was given only barley straw ad libitum and housed in a metabolism stall with water freely accessible.

\section{Experimental design}

The amount of energy and nitrogen supplements was according to the method of Henning et al. (1991). The amount of nitrogen supplement between treatments was isonitrogenous as $18.8 \mathrm{mg}$. The chemical composition of CMS and molasses is shown in Table 1.

Table 1. Nitrogen and sugar composition of CMS and molasses (\%)

\begin{tabular}{lcc}
\hline & $\begin{array}{c}\text { CMS } \\
\text { (DM basis) }\end{array}$ & $\begin{array}{c}\text { Molasses } \\
\text { (As fed basis) }\end{array}$ \\
\hline \hline DM & 59.62 & \\
Total-N & 9.20 & 0.66 \\
Ammonia-N & 8.05 & \\
Sugar & & 47.16 \\
\hline
\end{tabular}

\section{(1) Experiment 1}

The experimental treatments were 1) control consisting of $100 \mathrm{ml}$ culture, 2) control plus $1.92 \mathrm{~g}$ molasses and $204 \mathrm{mg}$ CMS and 3) control plus $1.92 \mathrm{~g}$ molasses plus $40 \mathrm{mg}$ urea. Incubation time was for $12 \mathrm{~h}$. Each treatment was repeated five times.

\section{(2) Experiment 2}

The experimental treatments were 1) $0 \mathrm{~h}$ and each time control consisting of $100 \mathrm{ml}$ culture, respectively 2) control plus $1.92 \mathrm{~g}$ molasses and $204 \mathrm{mg}$ CMS and 3) control plus $1.92 \mathrm{~g}$ molasses and $40 \mathrm{mg}$ urea. Incubation time was from 6 to $16 \mathrm{~h}$ at $2 \mathrm{~h}$ intervals. The experiment was repeated five times.

\section{(3) Experiment 3}

The experimental treatments were 1) $0 \mathrm{~h}$ and 10 h control consisting of $100 \mathrm{ml}$ culture, respectively 2) control plus $204 \mathrm{mg}$ CMS and $1.92 \mathrm{~g}$ molasses 3) control plus $204 \mathrm{mg}$ CMS and $0.906 \mathrm{mg}$ sugar. Incubation time was for $10 \mathrm{~h}$. Each treatment 
was repeated five times.

\section{(4) Experiment 4}

The experimental treatments were 1) $0 \mathrm{~h}$ and $2 \mathrm{~h}$ control consisting of $100 \mathrm{ml}$ culture, respectively 2) control plus $0.906 \mathrm{~g}$ sugar and $204 \mathrm{mg}$ CMS 3) control plus $0.906 \mathrm{~g}$ sugar and $40 \mathrm{mg}$ urea. Incubation time was for $2 \mathrm{~h}$. Each treatment was repeated five times.

\section{Experimental procedure}

\section{(1) Inoculum preparation}

Samples of rumen liquor were obtained under suction by inserting a $30 \mathrm{~cm}$ long metal tube, in which a series of holes had been bored along the length, through the rumen cannula into the posterior sac of the rumen. The collected rumen liquor was filtered through 4 layers of muslin to remove large food particles. This filtrate was immediately centrifuged at $1000 \mathrm{~g}$ for 5 minutes at $30^{\circ} \mathrm{C}$ to remove protozoa and solid food particles. The bacteria-containing supernatant was diluted five-fold with pre-warmed $\left(39^{\circ} \mathrm{C}\right) \mathrm{CO}_{2}$ saturated buffer solution (Table 2) to obtain the inoculum for batch culture incubation (Henning et

Table 2. Rumen buffer solution ${ }^{1), 2)}$

\begin{tabular}{cc}
\hline \multicolumn{1}{c}{ Ingredient } & Amounts \\
\hline \hline Macrominerals & $\mathrm{g} / \mathrm{l}$ \\
$\mathrm{NaHCO}_{3}$ & 8.75 \\
$\mathrm{Na}_{2} \mathrm{HPO}_{4} \cdot 12 \mathrm{H}_{2} \mathrm{O}$ & 17.9 \\
$\mathrm{KH}_{2} \mathrm{PO}_{4}$ & 6.8 \\
$\mathrm{MgSO}_{4} \cdot 7 \mathrm{H}_{2} \mathrm{O}$ & 0.15 \\
$\mathrm{Microminerals}^{3)}$ & $\mathrm{mg} / \mathrm{l}$ \\
$\mathrm{CaCl}_{2}$ anhydrous & 16.25 \\
$\mathrm{MnCl}_{2} \cdot 4 \mathrm{H}_{2} \mathrm{O}$ & 12.5 \\
$\mathrm{CoCl}_{2} \cdot 6 \mathrm{H}_{2} \mathrm{O}$ & 1.25 \\
$\mathrm{FeSO}_{4} \cdot 7 \mathrm{H}_{2} \mathrm{O}$ & 10.00 \\
\hline
\end{tabular}

1) Saturated with oxygen-free $\mathrm{CO}_{2}$ before using. Final $\mathrm{pH}$ was adjusted at 6.8 .

2) Distilled water was boiled before using.

3) $\mathrm{CaCl}_{2}$, anhydrous, $16.25 \mathrm{~g} ; \mathrm{MnCl}_{2} \cdot 4 \mathrm{H}_{2} \mathrm{O}, 12.50 \mathrm{~g}$; $\mathrm{CoCl}_{2} \cdot 6 \mathrm{H}_{2} \mathrm{O}, 1.25 \mathrm{~g}$; and $\mathrm{FeSO}_{4} \cdot 7 \mathrm{H}_{2} \mathrm{O}, 10.0 \mathrm{~g}$ were dissolved in $100 \mathrm{ml}$ of distilled water. One-tenth $\mathrm{ml}$ of this solution was added to 1 liter of rumen buffer. al., 1991).

(2) Incubation

Representative aliquots of inoculum were dispensed into each glass fermentation bottle (100 $\mathrm{ml}$ inoculum per bottle) in a shaking water bath at $39^{\circ} \mathrm{C}(100$ RPM). All fermentation bottles were continuously flushed with $\mathrm{CO}_{2}$ throughout the each incubation periods.

\section{(3) Sample collection}

To stop the activity of microbes after finishing incubation, the $\mathrm{pH}$ was lowered below 2 by adding $5 \mathrm{~N}$ sulphuric acid (6 ml per bottle) and stored at $4^{\circ} \mathrm{C} .30 \mathrm{ml}$ of each culture was dispensed into a glass tube, then centrifuged $(1000 \mathrm{~g}, 5$ minutes) to remove sediment of CMS. The supernatant was centrifuged at 26,000 $\mathrm{g}$ for 15 minutes at $4^{\circ} \mathrm{C}$. The supernatant was decanted and used for determining ammonia nitrogen and total nitrogen. The remaining bacterial pellet was resuspended in distilled water and this suspension was similarly centrifuged. The supernatant was decanted and the washed bacterial pellet analysed for microbial $\mathrm{N}$.

\section{Chemical analysis}

A known weight of sample was oven dried at $100^{\circ} \mathrm{C}$ for $15 \mathrm{~h}$ and the dry matter (DM) expressed as a percentage of fresh weight. The supernatant after centrifuging at 26,000 $\mathrm{g}$ was analysed for ammonia nitrogen and total nitrogen and the bacterial pellet was analysed for total nitrogen by a Kjeldahl procedure using a Kjeltec Auto 1030 analyser (Foss UK Ltd, Didcot, Oxon, UK)

\section{Statistical analysis}

The results were subjected to analysis of variance to examine the treatment effects using Genstat 5 (Lawes Agricultural Trust, 1990). All differences between treatments were inspected by the least significant difference (LSD) method at the $5 \%$ level. 


\section{RESULTS}

\section{Experiment 1}

There was no significant difference in the concentration of microbial nitrogen between molasses /CMS and molasses/urea treatments, although there were greater decreases in ammonia concentration and $\mathrm{pH}(\mathrm{P}<0.001)$ with the molasses/CMS treatment (Table 3).

The amount of total nitrogen supplied was $38.22 \mathrm{mg}$ (12.7, 18.8 and $6.72 \mathrm{mg} \mathrm{N}$ in molasses, CMS or urea and control, respectively) and that recovered by analysis was 39.18 and $39.10 \mathrm{mg}$ $\mathrm{N} / 100 \mathrm{ml}$ culture in molasses/CMS and molasses/ urea treatments, respectively. When the sum of the concentration of microbial, ammonia and supernatant nitrogen was compared with that of nitrogen supplied, however, it was not in accordance with the amount of nitrogen supplied. All the nitrogen content in the culture, but not in the sediment which came from centrifuging at $1,000 \mathrm{~g}$ after incubation, was analysed. So it was assumed that the nitrogen loss came from the sediment.

\section{Experiment 2}

The concentration of microbial nitrogen is shown in Fig. 1. There were no significant differences between treatments throughout the 16

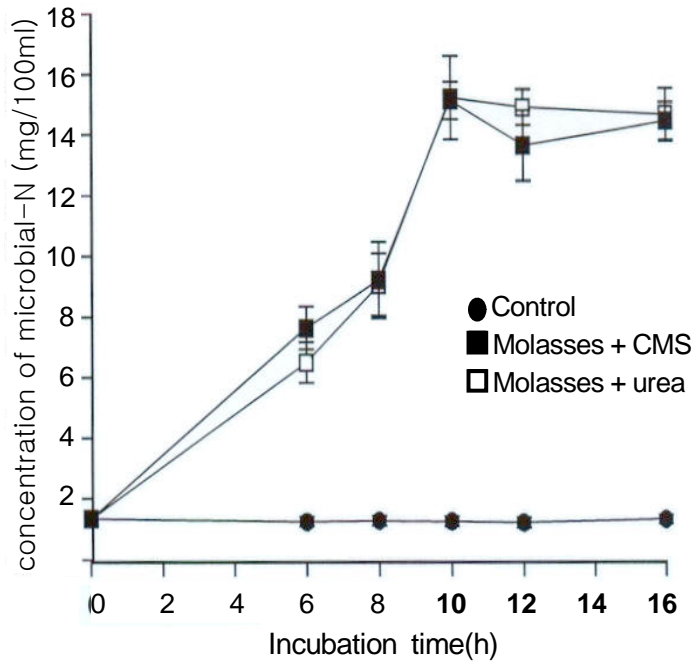

Fig. 1. The variation of the concentration of microbial-N throughout 16-h incubation period in experiment 2 .

h incubation period. Molasses/CMS treatment showed faster microbial protein synthesis until 8 $\mathrm{h}$ than molasses/urea treatment. However, during the last period, the microbial protein synthesis of molasses/urea remained slightly higher than that of the molasses/CMS treatment. In both treatments, the microbial protein synthesis was increased progressively until $10 \mathrm{~h}$.

The concentration of ammonia nitrogen is shown in Fig. 2. The concentration of ammonia nitrogen of molasses/CMS treatment was significantly decreased $(\mathrm{P}<0.001)$ during the incubation period except 12 and

Table 3. The concentration $(\mathrm{mg} / 100 \mathrm{ml})$ of nitrogen and $\mathrm{pH}$ of culture after $12 \mathrm{~h}$ incubation in experiment ${ }^{1)}$

\begin{tabular}{lccccc}
\hline & \multirow{2}{*}{ Control } & \multicolumn{2}{c}{ Molasses +} & \multirow{2}{*}{ SED } & \multirow{2}{*}{ P value } \\
\cline { 3 - 4 } & & CMS & Urea & & \\
\hline \hline Microbial-N & $2.24^{\mathrm{a}}$ & $7.79^{\mathrm{b}}$ & $7.61^{\mathrm{b}}$ & 0.396 & 0.001 \\
Ammonia-N $^{1)}$ & $2.99^{\mathrm{a}}$ & $9.22^{\mathrm{b}}$ & $11.17^{\mathrm{c}}$ & 0.392 & 0.001 \\
N of supernatant $^{2)}$ & & 13.33 & 12.90 & & \\
Total-N $^{3)}$ & 6.72 & 39.18 & 39.10 & & \\
$\mathrm{pH}$ & $7.00^{\mathrm{a}}$ & $5.90^{\mathrm{c}}$ & $6.14^{\mathrm{b}}$ & 0.017 & 0.001 \\
\hline
\end{tabular}

\footnotetext{
1) The ammonia nitrogen was the concentration in supernatant.

2) The value of nitrogen of supernatant was obtained after substracting the value of ammonia nitrogen from the total nitrogen of supernatant.

3) The total nitrogen was the concentration in $100 \mathrm{ml}$ culture.
} 


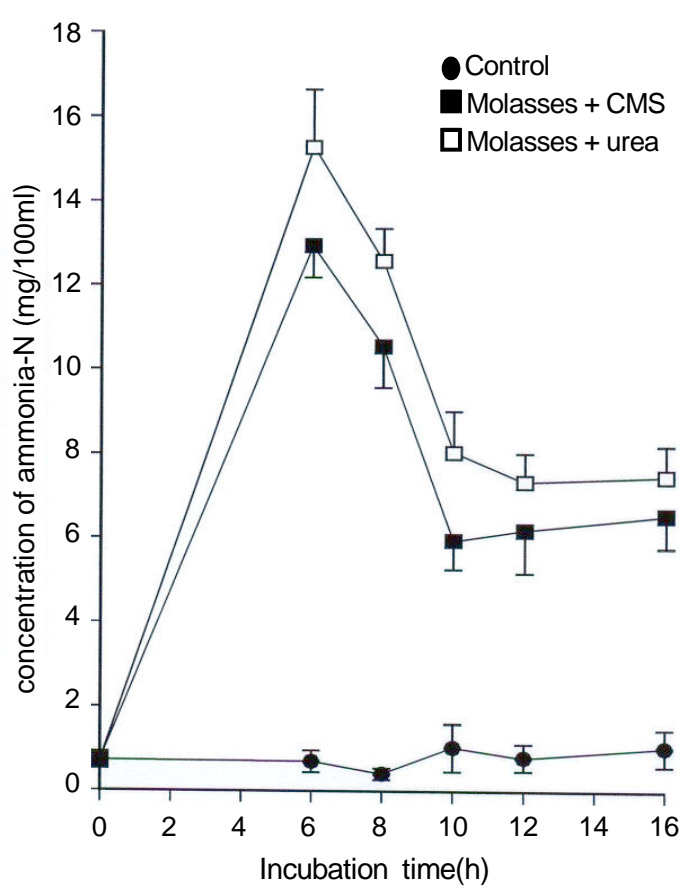

Fig. 2. The variation of the concentration of ammonia-N throughout $16-\mathrm{h}$ incubation period in experiment 2.

$16 \mathrm{~h}$. The concentration of ammonia nitrogen in both treatments was markedly decreased from 8 to $10 \mathrm{~h}$.

The change in $\mathrm{pH}$ of batch cultures is shown in Fig. 3. The $\mathrm{pH}$ of molasses/CMS treatment was significantly decreased $(\mathrm{P}<0.001)$ throughout the $16 \mathrm{~h}$ incubation period. In accord with the

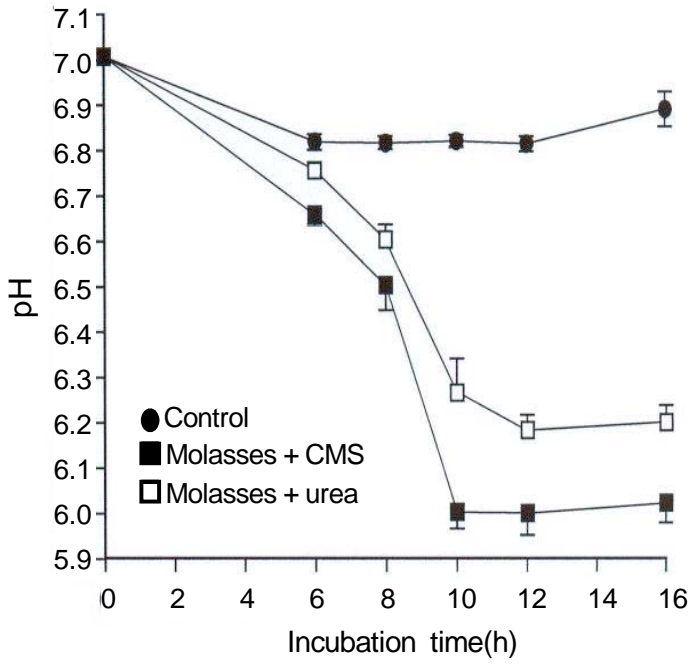

Fig. 3. The variation of $\mathrm{pH}$ throughout $16-\mathrm{h}$ incubation period in experiment 2 .

decrease of ammonia nitrogen, the $\mathrm{pH}$ was rapidly decreased from 8 to $10 \mathrm{~h}$.

\section{Experiment 3}

The results of experiment 3 are shown in Table 4. There were no significant differences in the concentration of microbial nitrogen and $\mathrm{pH}$ between CMS/molasses and CMS/sugar treatments. The concentration of ammonia nitrogen was significantly lower $(\mathrm{P}<0.001)$ for $\mathrm{CMS} /$ sugar

Table 4. The concentration $(\mathrm{mg} / 100 \mathrm{ml})$ of nitrogen and $\mathrm{pH}$ of culture in experiment 3

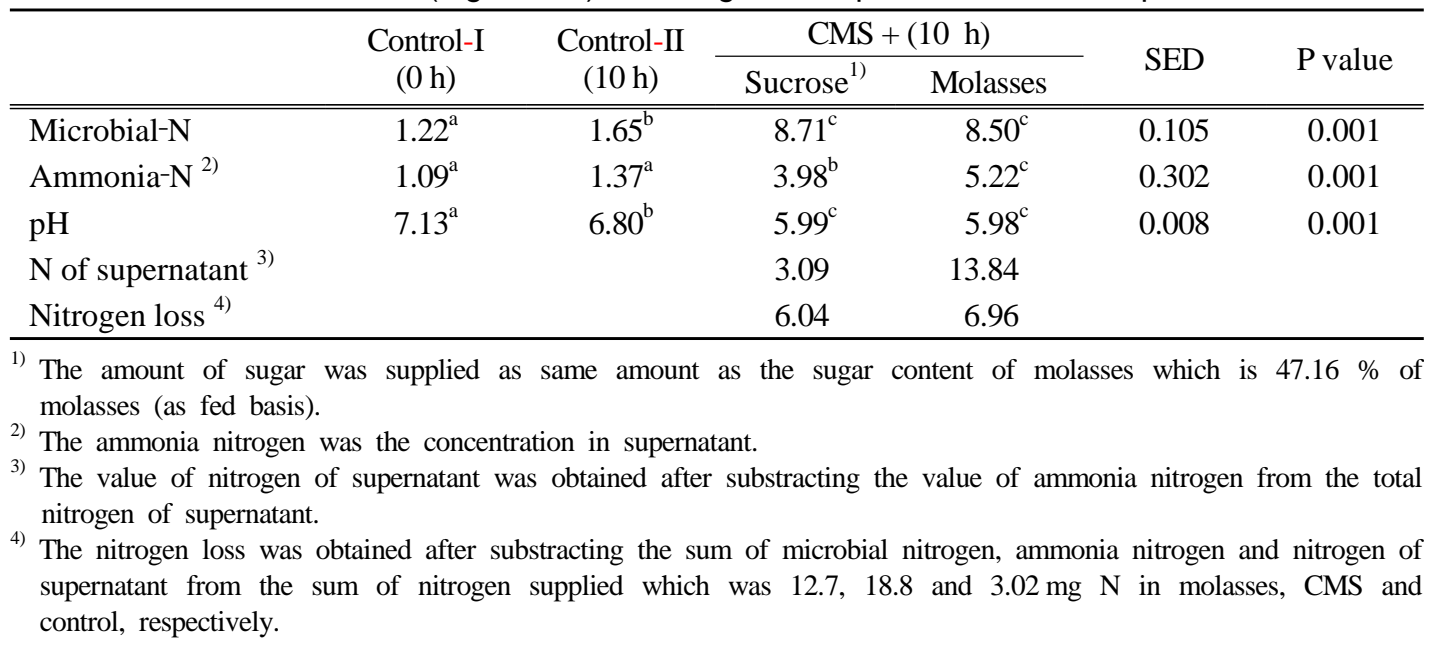


treatment compared with CMS/molasses treatment. The nitrogen of supernatant in molasses was much higher than in sugar treatment, although the nitrogen unaccounted for was similar for the two treatments.

\section{Experiment 4}

The results of experiment 4 are shown in Table 5. The concentration of microbial nitrogen in sugar/CMS was significantly increased $(\mathrm{P}<0.001)$ during $2 \mathrm{~h}$ incubation compared with sugar/urea treatment. Ammonia release from CMS was much faster $(\mathrm{P}<0.001)$ than from urea. In keeping with this, the nitrogen in the supernatant with the sugar/urea treatment was much higher than with the sugar/CMS. The nitrogen unaccounted for was similar for the two treatments. The $\mathrm{pH}$ for sugar/CMS was significantly lower than for sugar/urea $(\mathrm{P}<0.001)$.

\section{DISCUSSION}

As well as having the specific aim of evaluating of CMS as a nutrient for ruminal microbes, the present study had the additional objective of establishing a reliable incubation system in vitro.

In experiment 1 , there was sediment after centrifuging at $1,000 \mathrm{~g}$ after incubation in molasses/ CMS and molasses/urea treatments. Since it was expected that this low-speed residue must be essentially feed particles, it had to be excluded from the analysis of microbial nitrogen. However, when this was done, it was found that the overall recovery of total nitrogen was low, suggesting that the low-speed sediment contributed a high concentration of nitrogen, which suggested that the sediment was largely of microbial not feed origin (the concentration of nitrogen in feed particles would be very low). That the sediment was largely of bacterial origin was confirmed by microscopic examination. This meant that a considerable error would be introduced into the measurement of microbial nitrogen if this sediment were excluded. Indeed, such an underestimate was suggested by the fact that the measured rates of microbial nitrogen production were well below the theoretical value which is $19.3 \mathrm{~g}$ microbial $\mathrm{N} / \mathrm{kg}$ OM truly digested (Czerkawski, 1978). Inclusion of the sediment in the measurement led to rates of microbial nitrogen production that were much closer to theoretical value (from $9 \mathrm{mg} / 100 \mathrm{ml}$ without inclusion to $15 \mathrm{mg} / 100 \mathrm{ml}$ with inclusion). Further support for including the low-speed sediment in the microbial nitrogen fraction comes from the results of Experiment 3. Even when using ingredients that were completely soluble (sucrose, urea), the sediment was still evident. It is hard to see how this sediment could have been of feed origin.

Another incidental observation worthy of further comment is that the nitrogenous compounds in molasses appeared to be largely unavailable to ruminal bacteria. This is suggested by the results of Experiment 3. Even though the cultures would

Table 5. The concentration $(\mathrm{mg} / 100 \mathrm{ml})$ of nitrogen and $\mathrm{pH}$ of culture in experiment 4

\begin{tabular}{lcccccc}
\hline & Control-I & Control-II & \multicolumn{2}{c}{ Sucrose +(2 h) } & \multirow{2}{*}{ SED } & \multirow{2}{*}{ P value } \\
\cline { 4 - 5 } & $(0 \mathrm{~h})$ & $(2 \mathrm{~h})$ & CMS & Urea & & \\
\hline \hline Microbial-N & $1.52^{\mathrm{a}}$ & $1.54^{\mathrm{a}}$ & $1.81^{\mathrm{c}}$ & $1.58^{\mathrm{b}}$ & 0.034 & 0.001 \\
Ammonia-N $^{1)}$ & $0.46^{\mathrm{a}}$ & $0.40^{\mathrm{a}}$ & $14.42^{\mathrm{c}}$ & $6.19^{\mathrm{b}}$ & 0.512 & 0.001 \\
$\mathrm{pH}$ & $7.00^{\mathrm{a}}$ & $6.81^{\mathrm{bc}}$ & $6.78^{\mathrm{c}}$ & $6.84^{\mathrm{b}}$ & 0.008 & 0.001 \\
N of supernatant $^{2)}$ & 0.64 & 1.09 & 3.91 & 12.87 & & \\
Nitrogen loss $^{3)}$ & & & 1.69 & 1.19 & & \\
\hline
\end{tabular}

1) The ammonia nitrogen was the concentration in supernatant.

2) The value of nitrogen of supernatant was obtained after substracting the value of ammonia nitrogen from the total nitrogen of supernatant.

3) The nitrogen loss was obtained after substracting the sum of microbial nitrogen, ammonia nitrogen and nitrogen of supernatant from the sum of nitrogen supplied which was 18.8 and $3.03 \mathrm{mg} \mathrm{N}$ in CMS or urea and control, respectively. 
be expected to be nitrogen-limited, the use of molasses ( $4 \% \mathrm{CP}$ ) compared with sucrose (zero nitrogen) led to no increase in the yield of microbial nitrogen. The implication is that the nitrogen constituents of molasses are unavailable or, alternatively, an adaptation period is required before they can be degraded by ruminal organisms.

Again, it is worth noting that the release of ammonia from urea was slow in this system. This probably reflects a deficiency of urease activity arising from the five-fold dilution of rumen liquor with buffer. In contrast, CMS contains mainly ammonium salts which are instantaneously available for microbial metabolism. This slow release of $\mathrm{NH}_{3}$ from urea may have handicapped urea as a nitrogen source in the in vitro system by causing a degree of asynchrony between $\mathrm{NH}_{3}$ and energy (ATP) availability (Johnson, 1976). It is important to note that this would not reflect the position in vivo where urea hydrolysis would be expected to be very rapid. Mahadevan et al. (1976) reported that urease was not inhibited by ammonia concentrations between $1 \mathrm{mM}$ and $40 \mathrm{mM}$ which are values commonly found in rumen. Again, it was suggested that urease activity is generally more than sufficient to provide ammonia from urea rapidly enough for microbial protein synthesis (Nikolic et al., 1980). Such observations highlight the need to carefully evaluate in vitro incubations to establish their inherent limitations. Only when these limitations are fully recognized and allowed for can the results be applied to the situation pertaining in vivo.

Another observation that should be investigated is the lower $\mathrm{pH}$ values that consistently occur with CMS compared urea. Since, apparently, this cannot be explained by the $\mathrm{pH}$ of CMS itself, it suggests that a faster fermentation rate may be induced by CMS but the mechanism underlying such an effect is not known.

As the sources of CMS used in other studies were variable it could be expected that the results from those studies were variable. This makes difficult to compare our results to others. In a dry matter digestion study in vitro using
CMS from lysine production (Hannon and Trenkle, 1990), microbial digestion was enhanced more by the addition of CMS than by the addition of urea to $100 \mathrm{mg}$ of cellulose. But these stimulatory effects of CMS were absent when the amount of cellulose was increased. The authors concluded that the nitrogen in CMS was available to rumen microorganisms growth. In an in vivo study using the same CMS as in the present study, it showed that, compared with urea treatment, microbial protein synthesis tended to be increased when the allantoin/creatinine ratio was used as an index of microbial protein production (Yeo et al., 2004).

In conclusion, the results of the present studies suggest that the feed value of CMS as a source of nitrogen for ruminal bacteria was similar to that of urea when it was estimated in vitro. In addition, these investigations have led to the development of a useful in vitro incubation technique that has shown itself to be responsive to changes in the supply of fermentable energy and nitrogen substrates. It is likely that the technique could be further refined to include measurement of total and individual volatile fatty acids which make it of even greater value by allowing its use for a wider range of investigations. As it stands, the technique provides an invaluable screening method for use prior to experimentation in vivo.

\section{ABSTRACT}

A series of four in vitro experiments were conducted to evaluate condensed molasses solubles (CMS) as a source of nitrogen for ruminal microbes. In experiment 1 , as compared with urea, the value of CMS as a nitrogen source was examined. In experiment 2, to determine the time needed for maximal response of microbial synthesis, the treatments were incubated for increasing times (from $6 \mathrm{~h}$ to $16 \mathrm{~h}$ ). Because a sediment that was assumed to cause nitrogen loss was found after incubation in experiments 1 and 2, it was decided to avoid formation of sediment using sugar instead of molasses or a shorter time incubation (experiments 3 and 4). Furthermore, in 
experiment 4, because the extent to which ammonia nitrogen is released from CMS and urea before $6 \mathrm{~h}$ of incubation was uncertain, it was decided to examine the peaks of concentrations of ammonia nitrogen released from CMS and urea by sampling after $2 \mathrm{~h}$ incubation. There was no significant difference in the concentration of microbial-N between molasses/CMS and molasses/ urea treatments in experiment 1 , although there were greater decreases in ammonia concentration with the molasses/CMS treatment. The microbial protein synthesis was increased progressively until $10 \mathrm{~h}$ for both treatments (experiment 2). Although ingredients that were completely soluble (sucrose, urea) were used in experiment 3 , the sediment was still evident suggesting that the sediment was largely of microbial not feed origin. Ammonia release from CMS was much faster than from urea during $2 \mathrm{~h}$ incubation. In conclusion, the results of the present studies suggest that the feed value of CMS as a source of nitrogen for ruminal bacteria was similar to that of urea when it was estimated in vitro.

(Key words : Condensed molasses solubles (CMS), Microbial protein synthesis, Rumen)

\section{REFERENCES}

1. Chen, M. C., Ammerman, C. B., Henry, P. R., Palmer, A. Z. and Long, S. K. 1981. Citrus condensed molasses solubles as an energy source for ruminants. J. Anim. Sci., 53:253-259.

2. Czerkawski, J. W. 1978. Reassessment of efficiency of synthesis of microbial matter in the rumen. J. Dairy Sci., 61:1261-1273.

3. Ha, J. K., Kim, H. D., Shim, S .S., Lee, J. H., Ko, Y. G., Kwack, B. O., Lee, S. S., Kim, W. Y. and Han, I. K. 1998. Studies on nutritive value of lysine fermentation by-product as a protein source for ruminants. I. Chemical composition and effects of different levels of lysine fermentation by-product on in vitro nutrient digestibility and rumen fermentation and performance of Holstein cows. Korean J. Anim, Nutri. Feedstuffs, 22(6): 371-380.
4. Hannon, K. and Trenkle, A. 1990. Evaluation of condensed molasses solubles as a nonprotein nitrogen source for ruminants. J. Anim. Sci., 68:2634-2641.

5. Henning, P. H., Steyn, D. G. and Meissner, H. H. 1991. The effect of energy and nitrogen supply pattern on rumen bacterial growth in vitro. Anim. Prod., 53:165-175.

6. Johnson, R. R. 1976. Influence of carbohydrate solubility on non-protein nitrogen utilization in the ruminant. J. Anim. Sci., 43:184-191.

7. Karalazos, A. and Swan, H. 1977. The nutritional value for sheep of molasses and condensed molasses solubles. Anim. Feed Sci. Tech., 2:143-152.

8. Lawes Agricultural Trust. 1990. Rothamsted Experimental Station, Harpenden, Hertfordshire UK.

9. Lee, J. H., Kwack, B. O., Kim, H. D., Shim, S. S., Ko, Y. G., Lee, S. S., Kim, W. Y., Ha, J. K. and Han, I. K. 1998. Studies on nutritive value of lysine fermentation by-product as a protein source for ruminants. $\square$. Effects of different levels of lysine fermentation by-product on the nutrient digestibility and rumen fermentation in sheep and on the performance of korean native bulls. Korean J. Anim. Nutri. Feedstuffs, 22(6): 381-390.

10. Mahadevan, S., Sauer, F. and Erfle, J. D. 1976. Studies on bovine rumen bacterial urease. J. Anim. Sci., 42:745-753.

11. Nikolic, J. A., Pavlicevic, A., Zeremski, D. and Negovanovic, D. 1980. Adaptation to diets containing significant amounts of non-protein nitrogen. In Digestive Physiology and Metabolism in Ruminants, pp. 603-620, Ed Y. Ruckebush and P. Thivend. MTP Press, Lancaster, England.

12. Potter, S. G., Moya, A., Henry, P. R. and Palmer, A. Z. 1985. Sugarcane condensed molasses solubles as a feed ingredient for finishing cattle. J. Anim. Sci., 60:839-846.

13. Yeo, J. M., Jeong, S. G., Ahn, B. S., Kim, H. S., Kim, C. H. and Shin, H. T. 2004. The effects of condensed molassessolubles (CMS)/molasses mixtures on ruminal microbial protein synthesis. J. Anim. Sci. Tech. (Kor.), 46(1):61-68.

(접수일자 : 2006. 4. 10./ 채택일자 : 2006. 7. 3.) 